Original Research Paper

\title{
Footing Under Static Loading: Land Subsidence
}

\author{
Mochamad Arief Budihardjo, Su Yang, Amin Chegenizadeh and Hamid Nikraz \\ Department of Civil Engineering, Curtin University, Perth, Australia
}

Article history

Received: 12-05-2014

Revised: 22-08-2014

Accepted: 26-02-2015

Corresponding Author: Mochamad Arief Budihardjo Department of Civil

Engineering, Curtin University, Perth, Australia

Email: m.budihardjo@student.curtin.edu.au

\section{Introduction}

The phenomena of ground surface sinking as a result of overburden stress on the ground surface and over extraction of ground water has gained more attention worldwide (Chaussard et al., 2014). The excessive subsidence of footing has incurred widespread concern due to its influence on the stability and serviceability of foundations and the buildings above them. Factors such as the lowering of water levels, transported deposits, imposition of extra loading etc. will all cause subsidence of land and the footings established upon it. Among all of the subsidence triggers, the lowering of the water level is of particular concern due to the prevalence of water exploitation activities around the world arising from increasing water demand. Removal of water from soil layers, especially from compressible and highly permeable layers, will cause large and rapid land subsidence. Water pumping along wells is a typical means of groundwater exploitation.

A number of case studies have examined this issue. For instance, in Hanoi, various kinds of structures including roads and buildings have been damaged by settlement (Dang et al., 2014). Similarly, in Mexico heavy water pumping in the middle of city has caused extensive land subsidence in previous decades, resulting in severe harm to building foundations, transportation and sewage systems (Pacheco-Martínez et al., 2013). There have also been a number of other studies into municipal subsidence caused by lowering of groundwater levels (Shi et al., 2007; Zhang et al., 2014).

Increases in the effective stress and both permanent and irrecoverable settlements of underlying soil are believed to be fundamental mechanisms of land subsidence along with water pumping and the magnitude of subsidence depends on the increase in the effective stress and the decrease in the water head (Galloway and Burbey, 2011).

Budhu and Adiyaman (2010) established a governing formulation for stress changes in the case of groundwater pumping by dividing land subsidence into consolidation (vertical compression), shear displacement and macro rotation. Using this mechanism, Budhu (2011) studied earth fissure formation on a unconfined aquifer alluvium. Budhu and Adiyaman (2013) also find that number of clay areas and wells and their locations were considered to affect ground surface subsidence and profile (Budihardjo et al., 2014).

In considering the damage to footings that subsidence may cause, Shahriar et al. (2013) used laboratory testing and numerical verification to carry out a quantitative investigation of the influence of water table fluctuation 
on the settlement of various types of foundations. They also considered other parameters like soil density, stress level and foundation shape. It is important to numerically evaluate the characteristics and magnitude of influence caused by subsidence and its relevant parameters. Moreover, footings subject to different modes of load, such as bending and vertical pressure, may show different responses and have a different impact on the underlying soil when subsidence happens. These are the aspects that are investigated in this study. In Curtin University, Budihardjo et al. (2014) investigated a parametric study on clay zones effect on land subsidence. This study is part of a big project on subsidence in Curtin University. This study also extents the knowledge of footing subsidence by considering various well location and different load on footing.

\section{Materials and Methods}

\section{Software}

Curtin University's geotechnical software PLAXIS 2D was used for the numerical simulation in this study (PLAXIS 2D Software, 2012). PLAXIS is a computer program with the ability to calculate consolidation phenomena based on Biot's consolidation theory. This software can be used to analyze the deformation and characteristics of various soils in a way that approaches the actual behavior (Brinkgreve et al., 2010). The program has a user-friendly graphical interface, which enables the user to simulate various aquifer scenarios. The finite element method is used for the calculation of deformation analysis and various stability analyses for a variety of geotechnical applications. Also, based on a cross-section of the state, a mesh element and geometry model can be created, which allows the soil to be analysed sufficiently close to the input data. In this case, plane strain or axisymmetry can be used for modelling. The hydrostatic pressure of the soil is taken into account when groundwater is present. Triangular elements with a choice of six nodes (points) or 15 points are available in PLAXIS, which consists of four sub-programs, namely input, calculation, output and curves. It is widely accepted that results from PLAXIS are reliable. PLAXIS also has been used to analyse the association of soil and structural foundation (Huat and Mohammed, 2006).

\section{Soil Model}

Sand was selected to constitue the models. The sand has permeability $5 \times 10^{-2} \mathrm{~cm} / \mathrm{sec}$, with effective fiction angle $35^{\circ} \mathrm{C}$. Both the stress-strain behavior and the consolidation of the soil are taken into account in the model.

\section{Simulation}

This study investigated the influence of well number and well location on footing subsidence. A point load of
$100 \mathrm{kN} / \mathrm{m}$ was applied on the left side of the footing and a bending moment of $100 \mathrm{kNm} / \mathrm{m}$, plus two different distributed loads of 150 and $300 \mathrm{kN} / \mathrm{m}$. The model area was $50 \times 200 \mathrm{~m}$. The well discharge rate was $20 \mathrm{~m}^{3} /$ day for each well. The well depth was $40 \mathrm{~m}$ below the surface in two cases. The initial groundwater level was set at $10 \mathrm{~m}$ below the surface at the beginning of all stages and a transient flow model was used throughout all models. In general, the control variables in the simulation were the pump rate, soil and footing parameters. Soe of the important parameters which were monitored in the simulation were ground surface and ground water level changes.

\section{Results}

\section{Single Well Model}

The single well model was developed by placing one well on the right hand side of the soil area. The well face was located $30 \mathrm{~m}$ from the right end of the footing and about $70 \mathrm{~m}$ from the point where load was applied. The groundwater extraction was set at $20 \mathrm{~m}^{3} /$ day. The vertical displacement of the ground surface area at some points (3 nodes) was recorded. The detail result are presented in Table 1.

\section{Two Wells Model}

The two well model was created by placing a new well on the left hand side of the soil area. The second well was located $30 \mathrm{~m}$ from the left corner of the footing. The depth of the well was fixed at $40 \mathrm{~m}$ under ground and the extraction capacity of the well was $20 \mathrm{~m}^{3} /$ day. In total, $40 \mathrm{~m}^{3}$ of groundwater was pumped out of the ground each day.

\section{Model with Doubled Distributed Load}

The effect of the magnitude of distributed load on footing subsidence for footings on sand aquifers with pumping wells was investigated. The distributed load on the footings was doubled to $300 \mathrm{kN} / \mathrm{m}$ for all single well, dual well and three well systems. The results are shown in Fig. 3 and 4 with the magnitude of deformation for significant points listed in Table 3 and 4.

\section{Discussion}

\section{Effect of Well Numbers/Locations}

According to Fig. 1, the maximum deformation hap.pens at node 475 , located in the middle of the footing, with a deformation of $152.262 \times 10^{-3} \mathrm{~m}$. The left hand edge of the footing (node 691) deforms more than the right hand verge as a result of a point load and bending moment applied in left hand verge of the footing. Interestingly, there was more displacement 
occur in the right hand side area of the soil model which is slightly more than displacement on the left hand side of soil model. This is assumed to have been caused by an imbalance of the water head. The water level in the right side of soil model is lower than left area due to the location of pumping well. The footing was subjected to relatively lower displacement compared to the neighboring soil profile.

When two wells are installed symmetrically with respect to the centre of the footing, the maximum vertical displacement also occurs at node 404 (Fig. 2), which is also the centre of the footing. From the PLAXIS results, the maximum displacement was $163.78 \times 10^{-3} \mathrm{~m}$ (Table 2), slightly higher than that of the one well system discussed above. Also, the water table was a bit lower and level after pumping compared to the single well system, which corresponds well to the greater subsidence compared to Fig. 1 and Table 1. In theory, this could have been due to a higher effective stress and grain repositioning. However, the location corresponding to the lowest point of the water table is not where the maximum displacement occurs. According to the surface profile, the displacement increases when the point approaches the centre of the footing. The surface profile is generally sagging in the area where the footing is placed. On the other hand, land subsidence simulation without any footing or load created the lowest sagging area close to the wellhead location (Budihardjo et al., 2014).

Table 1. Data of the points on the surface profile of Fig. 1

\begin{tabular}{ll}
\hline Node & y deformation $\left(10^{-3} \mathrm{~m}\right)$ \\
\hline 691 & 127.641 \\
475 & 152.262 \\
311 & 115.498 \\
\hline
\end{tabular}

Table 2. Data of the points on the surface profile of Fig. 2

\begin{tabular}{ll} 
Node & y deformation $\left(10^{-3} \mathrm{~m}\right)$ \\
\hline 729 & 149.066 \\
404 & 163.788 \\
307 & 127.770 \\
\hline
\end{tabular}

Table 3. Data of the points on the surface profile of Fig. 3

\begin{tabular}{ll}
\hline Node & y deformation $\left(10^{-3} \mathrm{~m}\right)$ \\
\hline 691 & 193.184 \\
475 & 252.245 \\
311 & 180.621 \\
\hline
\end{tabular}

Table 4. Data of the points on the surface profile of Fig. 4

\begin{tabular}{ll} 
Node & y deformation $\left(10^{-3} \mathrm{~m}\right)$ \\
\hline 729 & 149.066 \\
404 & 163.788 \\
307 & 127.770 \\
\hline
\end{tabular}
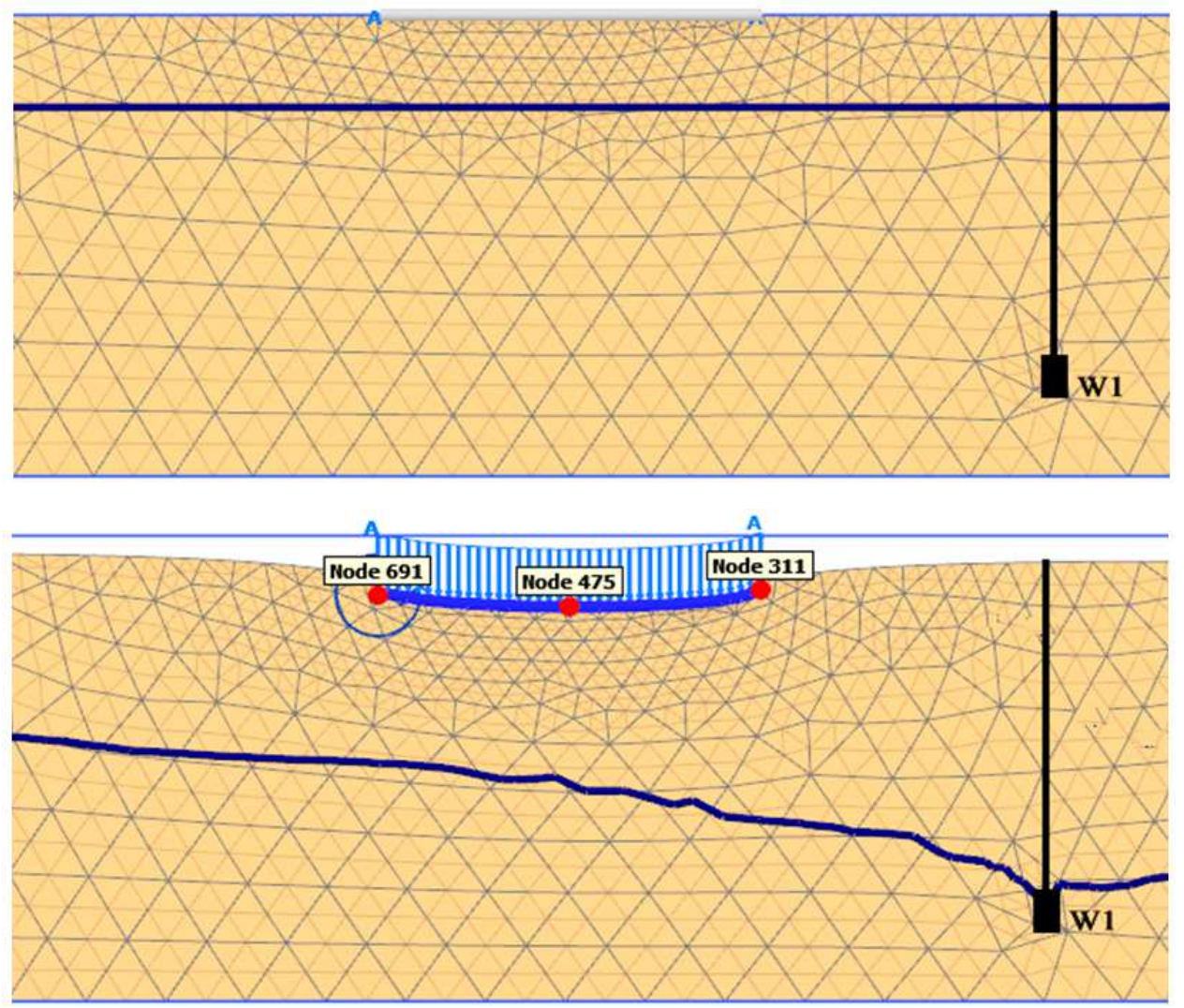

Fig. 1. Initial mesh (upper image) and final deformed mesh (lower image) of single well model with distributed load of $150 \mathrm{kN} / \mathrm{m}$ 

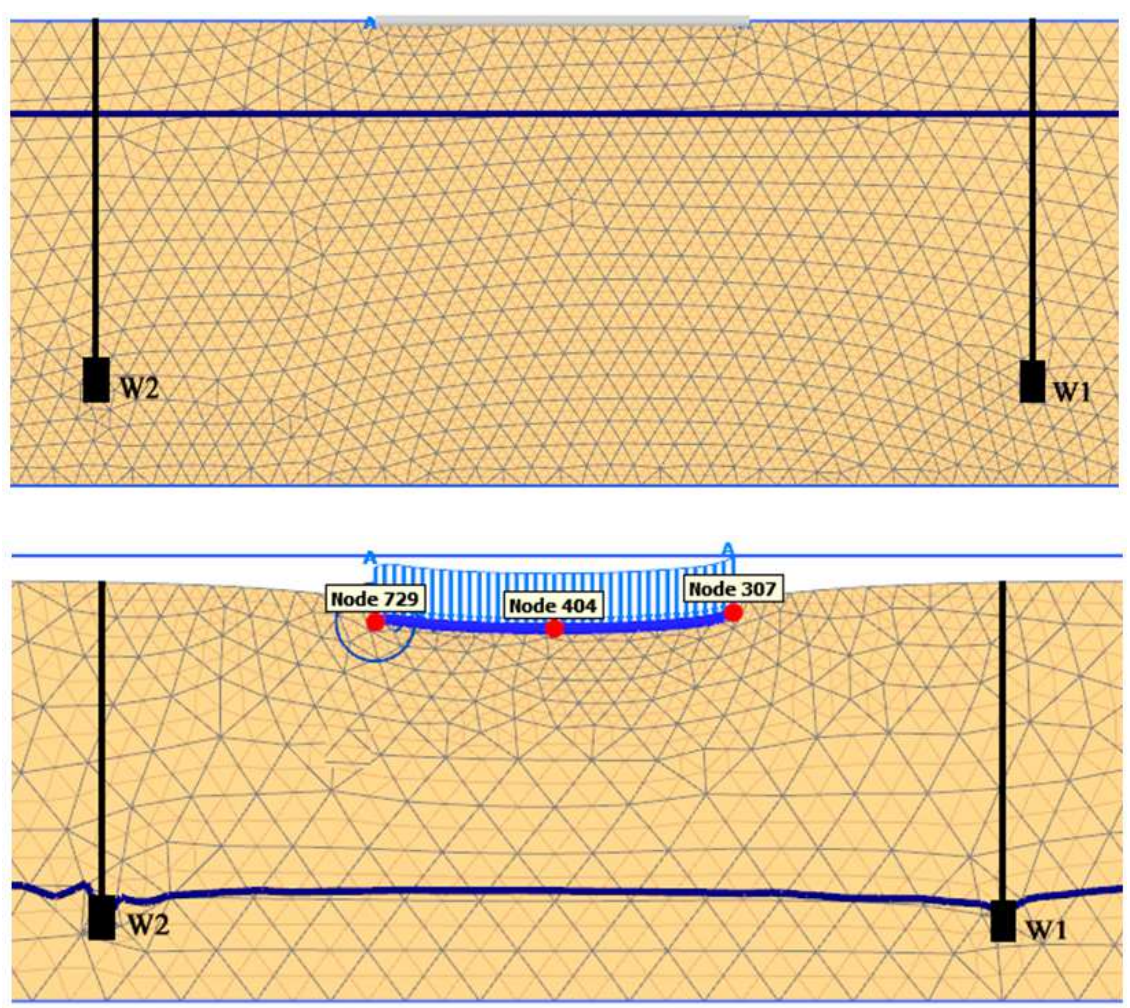

Fig. 2. Initial mesh (upper image) and final deformed mesh (lower image) of two well model with distributed load of $150 \mathrm{kN} / \mathrm{m}$

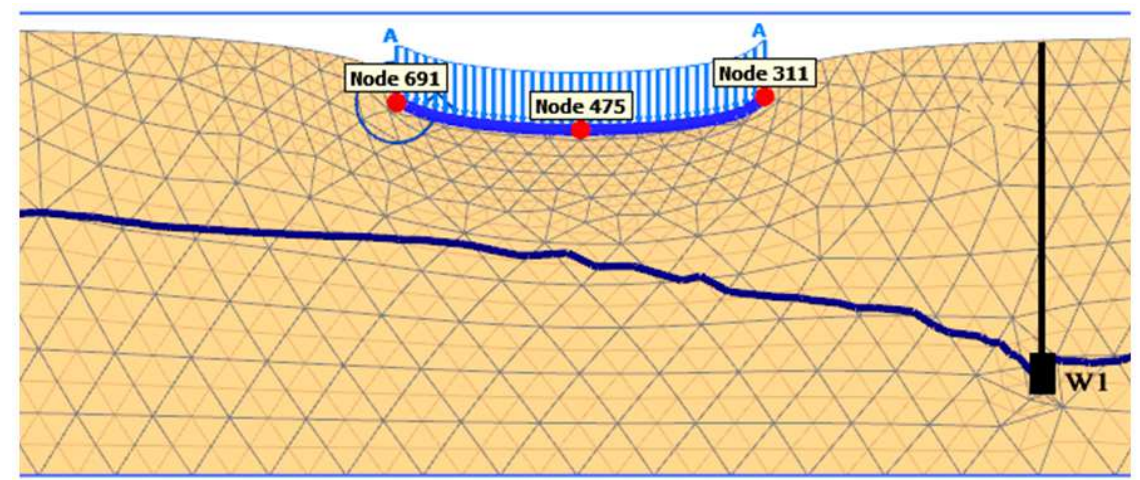

Fig. 3. Deformed mesh of one well model with distributed load of $300 \mathrm{KN} / \mathrm{m}$

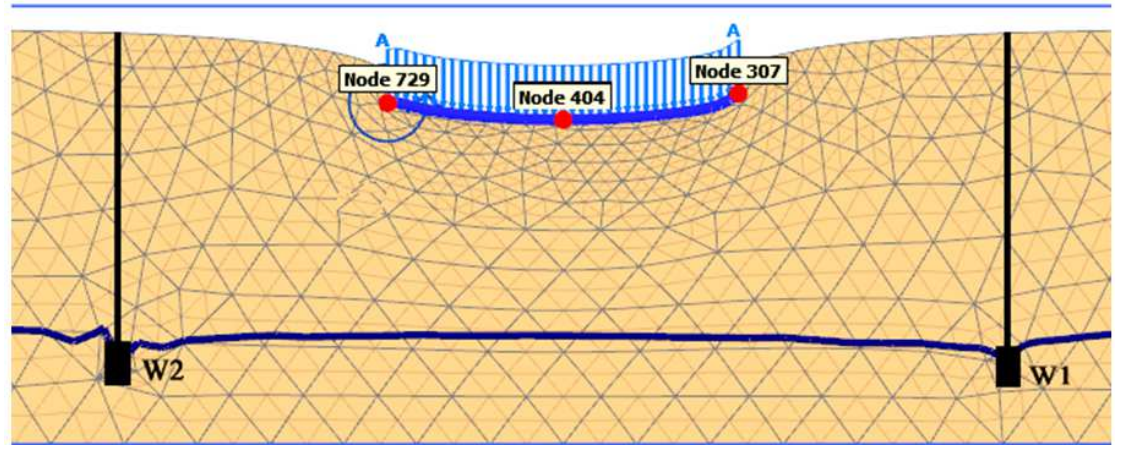

Fig. 4. Deformed mesh of two well model with distributed load of $300 \mathrm{KN} / \mathrm{m}$ 


\section{Effects of Load Magnitude}

Compared to the figures and tables illustrating the results for the models with a distributed load of 150 $\mathrm{kN} / \mathrm{m}$, the profiles for both the surface and footing for one and two systems remained the same. There was no change in symmetry or location of maximum subsidence for the models with the same well conditions but a different distributed load. For instance, both Fig. 1 and 3 (one well system) showed a sagging surface profiles in the footing area and the centre of footing as the location of maximum footing subsidence. Similar comparisons can be found between Fig. 2 and 4 .

The magnitude of subsidence increased with the increase in load. For example, the centre of the footing (node 475) in Fig. 3 and Table 3 showed a vertical deformation of $252.245 \times 10^{-3} \mathrm{~m}$, which is much greater to that seen in Fig. 1 and Table 1 (node 475) with the subsidence difference between those two points is about $99.983 \times 10^{-3} \mathrm{~m}$.

The same results can also be found between corresponding points between points in Table 2 and 4 . There are some values which vary slightly with each other, moreover, in the left and right edge areas of soil model, but these are negligible for the purposes of drawing a conclusion, since it is obvious they are due to inevitable computational variations.

As a result, the subsidence of footing is mainly affected by the load applied into the footing. Interestingly, even the applied load was distributed along the footing, however, more subsidence occurs in the middle of the footing compared to any other area. In the mean time, pumping wells and how much water is extracted has been lowering the water table and causing an increase in effective stress and vertical deformation along the ground surface area.

\section{Land Subsidence Prevention}

It is very useful to perform a regular measurement of ground water level to monitor pumping effect on ground water level. The data then can be analysed to develop local groundwater mapping which consists of discharge and recharge areas (Anomohanran, 2013). As an instance, in one of the research which was conducted by Sundara Rajulu and Rajani (2012) a geo-information system of ground water identification was developed using neural network and component analysis, which can also be used to monitor the ground water availability.

Furtheremore, instead of using advance technology, the ground water level monitoring can also be performed by a simple method which involving a number of control wells which function like piezometers. This method has also been widely applied by the landfill operator to control the concentration of pollution as well as measuring the ground water level (Benmenni and Benrachedi, 2010).
In order to reduce the potential of land subsidence which mostly occur in rapid development cities, urban management planning should consider ground water extraction policy and engage soil modelling approach to simulate any potential issues toward development of a city involving structural construction. A heavy structural construction which contribute to overburden stress on the ground surface should be precisely calculated and anticipated using computational simulation. Groundwater extractions should be taken into account as part of urban planning (Russo and Taddia, 2009). Soil simulation will be very useful tool to help avoiding potential problems related to land subsidence and structural failure in respect to ground water extraction.

\section{Conclusion}

PLAXIS software was used to investigate the influence of pumping well conditions on the subsidence of footing subjected to combined load conditions. Two PLAXIS models including one and two wells were made and the results of surface and footing deformation were presented in figures and tables. The following is a list of findings from this research:

- All well system has a generally even and symmetric surface profile with maximum subsidence at the centre of the footing

- Footing subsidence increases with the number of wells, with a two well system incurring much greater subsidence than a single well system

- On the scale investigated, changing the distributed load on the footing has great effect on the footing subsidence and the maximum footing subsidence occurs at the centre of the footing

- The well conditions described previously are the dominant factors affecting the behavior of the entire sand aquifers deformation with pumping wells

Future research should investigate other influences on footing subsidence, including the dynamics or earthquake load, the magnitude of water table influence, different footing shapes/rigidity, different soil types etc.

\section{Acknowledgement}

The first author sincerely acknowledges the funding received from the Directorate General of Higher Education (DGHE), Ministry of National Education, Republic of Indonesia in the form of a scholarship for his PhD studies. He would also like to thank and acknowledge the Department of Environmental Engineering, Diponegoro University which is providing extensive support during his $\mathrm{PhD}$ studies at Curtin University, Western Australia. 


\section{Funding Information}

The first author has received scholarship funding from the Directorate General of Higher Education (DGHE), Ministry of National Education, Republic of Indonesia.

\section{Author's Contributions}

Mochamad Arief Budihardjo: Participated in modelling development, helped in the result analysis and contributed to the writing of the manuscript.

Su Yang: Participated in modelling development, helped in the result analysis and contributed to the writing of the manuscript.

Amin Chegenizadeh: Provided the research idea/plan, coordinated the research, helped in the result analysis, coordinated and contributed to the writing of the manuscript and provided critical review of the manuscripts.

Hamid Nikraz: Provided the research idea/plan, helped in the result analysis, coordinated the research, contributed to the writing of the manuscript and provided critical review of the manuscripts.

\section{Ethics}

This article is original and has not been published anywhere else. The corresponding author confirms that all of the other authors have read and approved the manuscript and no ethical issues involved.

\section{References}

Anomohanran, O., 2013. Evaluation of aquifer characteristics in Echi, Delta State, Nigeria using well logging and pumping test method. Am. J. Applied Sci., 10: 1263-1269.

DOI: 10.3844/ajassp.2013.1263.1269

Benmenni, M.S. and K. Benrachedi, 2010. Impact of earthquake demolition debris on the quality of groundwater. Am. J. Applied Sci., 7: 545-550. DOI: 10.3844/ajassp.2010.545.550

Budhu, M., 2011. Earth fissure formation from the mechanics of groundwater pumping. Int. J. Geomechanics, 11: 1-11. DOI: 10.1061/(ASCE)GM.1943-5622.0000060

Budhu, M. and I. Adiyaman, 2013. The influence of clay zones on land subsidence from groundwater pumping. Groundwater, 51: 51-57. DOI: $10.1111 / \mathrm{j} .1745-6584.2012 .00943 . \mathrm{x}$

Budhu, M. and I.B. Adiyaman, 2010. Mechanics of land subsidence due to groundwater pumping. Int. J. Numerical Analytical Methods Geomechanics, 34: 1459-1478. DOI: 10.1002/nag.863

Budihardjo, M.A., A. Chegenizadeh and H. Nikraz, 2014. Land subsidence: The presence of well and clay layer in aquifer. Aus. J. Basic Applied Sci., 8: 217-224.
Brinkgreve, R.B.J., W.M. Swolfs, E. Engin, D. Waterman and A. Chesaru et al., 2010. PLAXIS 2D 2010. User Manual, PLAXIS bv.

Chaussard, E., S. Wdowinski, E. Cabral-Cano and F. Amelung, 2014. Land subsidence in central Mexico detected by ALOS InSAR time-series. Remote Sensing Environ., 140: 94-106. DOI: 10.1016/j.rse.2013.08.038

Dang, V. K., C. Doubre, C. Weber, N. Gourmelen and F. Masson, 2014. Recent land subsidence caused by the rapid urban development in the Hanoi region (Vietnam) using ALOS in SAR data. Natural Hazards Earth Syst. Sci., 14: 657-674. DOI: 10.5194/nhess-14-657-2014

Galloway, D.L. and T.J. Burbey, 2011. Review: Regional land subsidence accompanying groundwater extraction. Hydrogeol. J., 19: 1459-1486. DOI: $10.1007 / \mathrm{s} 10040-011-0775-5$

Huat, B.B.K. and T.A. Mohammed, 2006. Finite Element Study Using FE Code (PLAXIS) on the geotechnical behavior of shell footings. J. Comput. Sci., 2: 104-108. DOI: 10.3844/jcssp.2006.104.108

Pacheco-Martínez, J., M. Hernandez-Marin, T.J. Burbey, N. González-Cervantes and J.Á. Ortíz-Lozano et al., 2013. Land subsidence and ground failure associated to groundwater exploitation in the Aguascalientes Valley, Mexico. Eng. Geol., 164: 172-186. DOI: 10.1016/j.enggeo.2013.06.015

PLAXIS 2D Software, 2012. Licence to Curtin University Australia, Code: NP801PK 54aab534 421f3599, Service Nr: 2-1301835.

Russo, S.L. and G. Taddia, 2009. Groundwater in the urban environment: Management needs and planning strategies. Am. J. Environ. Sci., 5: 494-500. DOI: 10.3844/ajessp.2009.494.500

Shahriar, M.A., N. Sivakugan, A. Urquhart, M. Tapiolas and B.M. Das, 2013. A study on the influence of ground water level on foundation settlement in cohesionless soil. Proceedings of the 18th International Conference on Soil Mechanics and Geotechnical Engineering: Challenges and Innovations in Geotechnics, Sep. 2-6, Paris, France, pp: 953-956.

Shi, X.Q., Y.Q. Xue, S.J. Ye, J.C. Wu and Y. Zhang et al., 2007. Characterization of land subsidence induced by groundwater withdrawals in Su-Xi-Chang area, China. Environ. Geol., 52: 27-40. DOI: $10.1007 / \mathrm{s} 00254-006-0446-3$

Sundara Rajulu, N. and M. Rajani, 2012. The development of geo-information system for finding potential zones of water using environmental parameters and engineering. Am. J. Applied Sci., 9: 1448-1456. DOI: 10.3844/ajassp.2012.1448.1456

Zhang, Y., H. Gong, Z. Gu, R. Wang and X. Li et al., 2014. Characterization of land subsidence induced by groundwater withdrawals in the plain of Beijing city, China. Hydrogeol. J., 22: 397-409.

DOI: $10.1007 / \mathrm{s} 10040-013-1069-\mathrm{x}$ 